\title{
Corinthian Bronze and the Gold of the Alchemists
}

\author{
David M Jacobson \\ The Centre for Rapid Design and Manufacture, Buckingham Chilterns University College, High Wycombe, HP11 2JZ, UK
}

Received: 1 July 1999

Alloys that went under the name of Corinthian Bronze were highly prized in the Roman Empire at the beginning of the Christian era, when Corinthian Bronze was used to embellish the great gate of Herod's Temple in Jerusalem. From the ancient texts it emerges that Corinthian Bronze was the name given to a family of copper alloys with gold and silver which were depletion gilded to give them a golden or silver lustre. An important centre of production appears to have been Egypt where, by tradition, alchemy had its origins. From an analysis of the earliest alchemical texts, it is suggested that the concept of transmutation of base metals into gold arose from the depletion gilding process.

\section{CORINTHIAN BRONZE AND ITS IDENTIFICATION}

Ancient texts in Latin, Greek, Hebrew and Syriac refer to a type of metal called Corinthian Bronze which they prize above all other copper alloys. The Roman encyclopaedist, Pliny, who lived in the 1st century AD, states that Corinthian Bronze was valued "before silver and almost before gold" (1). He proceeds to discuss the appearance and composition of Corinthian Bronze as follows: "There are three kinds of this sort of bronze: a white variety, coming very near to silver in brilliance, in which the alloy of silver predominates; a second kind in which the yellow quality of gold predominates; and a third kind in which all the metals are blended in equal proportions." (2). In another passage, Pliny notes the pleasing appearance that the gold and silver alloying elements lend to Corinthian Bronze (3).

A story that circulated widely in the Roman Empire from the first century AD onwards related that Corinthian Bronze originated during the burning of Corinth at the time of its capture by the Romans in $146 \mathrm{BC}$ (4). According to this account, the alloy was first produced by accident when a building containing gold, silver and much copper caught fire and the metals alloyed together (5).

From these descriptions, we learn that Corinthian Bronze stood for a family of alloys containing gold and silver, although we must presume that copper was the main constituent because it is classified as bronze (aes in Latin), and is discussed by Pliny in the section of his encyclopaedia dealing with copper and bronze. However, Pliny indicates that their hue varied from golden to silvery, depending on the proportions of the precious metal additions, and it was this lustre that gave this bronze its attractive appearance. Both Cicero and Plutarch comment on the fact that, unlike other copper alloys, Corinthian Bronze was resistant to tarnishing (6). Tagged onto the first description of Corinthian Bronze, quoted above, is a mention of another bronze "valued in portrait statues and others for its particular colour" which approached "the appearance of liver and consequently called by a Greek name hepatizon, meaning liverish." Pliny adds that "it is far behind the Corinthian blend" in value. As we shall see, the reason why Pliny grouped this type of alloy together with Corinthian Bronze is that it also contained gold and silver, although in much smaller proportions.

Not surprisingly, it was the highly prized golden variety of Corinthian Bronze that received most attention from ancient writers. The Jewish authors of the Classical period were dazzled by the Corinthian Bronze doors of the Nicanor Gate in the Temple in Jerusalem. These doors "far exceeded in value those doors plated in silver and set with gold" (7). The Nicanor Gate formed the main entrance to the inner courts and was, doubtless, identical with the "Beautiful 


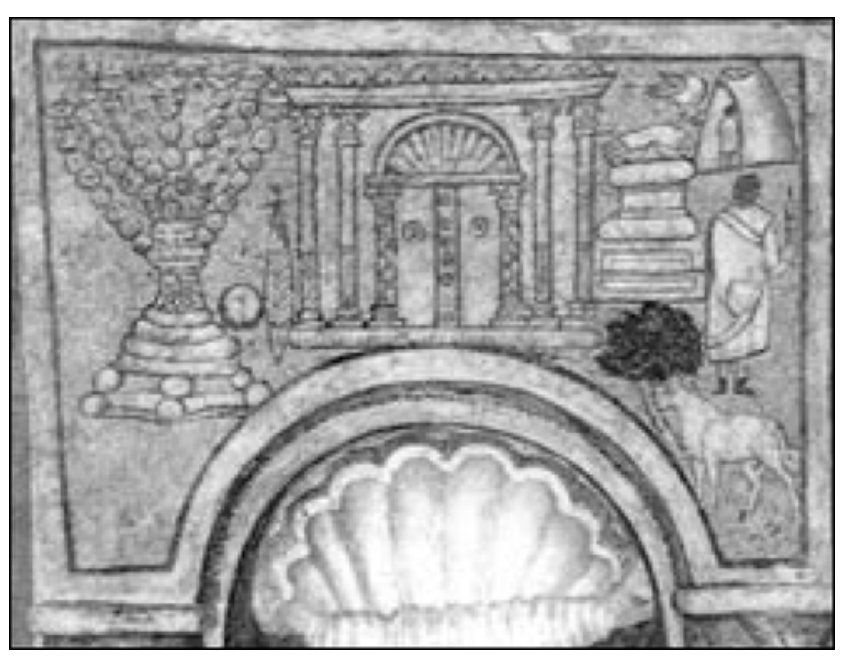

Figure 1 Possible representation of the Gate of Nicanor in the Temple in Jerusalem with its golden doon in a mural above the Torah shrine of the mid third century $A D$. synagogue of Dura Europos in Syria.

Gate" mentioned in Acts 3:2. According to the early Rabbinical work known as the Mishnah, this gate was the only one whose doors were not plated with gold, but composed of a bronze that shone "with a yellowish hue" (8). The Rabbinical authors agree explicitly with Josephus that these doors were made of Corinthian Bronze, "which was as beautiful as gold" (9). Nicanor, the donor of these precious doors, lived in the 1 st century AD in Alexandria but was buried in Jerusalem, where his inscribed ossuary has been found (10). According to the Jewish sources, the doors were brought from Alexandria, his native city, and it is reasonable to assume that they were also made there (11). The Nicanor Gate is possibly the structure depicted in fresco above the Torah shrine in the mid2nd century synagogue at Dura Europos on the Euphrates, which is preserved with the rest of the cycle of wall paintings in the Damascus Museum (12). The doors have two leaves, which are coloured yellow, to represent gold (see Figure 1).

Further association of Corinthian Bronze with a golden hue is to be found in Syriac sources. Thus, the Hebrew "goodly yellowed bronze" is rendered into Syriac as "Corinthian Bronze" in the Syriac "Peshitta" version of Ezra 8:27, datable to ca $200 \mathrm{AD}$ (13). Then, in a Syriac text attributed to Zosimus, one of the early luminaries of alchemy, but composed between the 7 th and 10 th centuries $A D$, a recipe is given "to make the golden or Corinthian colour" (14). Alongside this heading in the surviving manuscript, preserved in Cambridge, appears the symbol $\oplus$, which primarily represents the sun, but also the associated colour (yellow) and metal (gold) (15). The same manuscript also contains an abbreviated recipe for making "black Corinthian metal" (16). This would seem to refer to Pliny's dark-hued hepatizon bronze. Evidently, by the time that this text was composed, a blurring of the definition of Corinthian Bronze had occurred. Like Pliny's hepatizon, the black Corinthian metal is recommended in the Syriac text for use in statues.

A later document, a lexicon composed in the 10th century AD by the Syriac scholar Bar Bahlul, refers to Corinthian Bronze (17). Bar Bahlul agrees with Pliny that it is "part silver, part gold and part copper" and he adds that it is "bronze from which one makes gold and silver." This last statement finds an interesting echo in a recipe preserved in the Leiden Papyrus X, described below.

\section{CORINTHIAN BRONZE AND DEPLETION GILDING}

By scouring the ancient Greek, Latin and Syriac literature, it is possible to reconstruct the manufacture of Corinthian Bronze (18). We learn that its production involved further processing after alloying. This included a heat-treatment followed by a quench and burnishing (19). All these constituent steps are consistent with depletion gilding (or silvering), whereby copper is oxidized and removed from the surface of the bronze item by acid pickling, leaving the surface with a gold (or silver) layer, as explained below.

The alloying and processing technology suggested by the sources for the production of Corinthian Bronze is articulated in a recipe contained in the Leiden Papyrus $\mathrm{X}$ from Thebes in Egypt, the oldest surviving metallurgical text $(20,21)$. The papyrus appears to date from the fourth century $\mathrm{AD}$, but it has been shown that several of its recipes derive from even more ancient compilations (22). The relevant recipe (No. 15) describes a process called "the colouration (chrôsis) of gold":

"To colour gold, to render it fit for usage. Misy, salt and vinegar accruing from the purification of gold; mix it all and throw in the vessel [which contains it] the [debased] gold described in the preceding preparation; let it remain some time, [and then] having drawn [the gold] from the vessel, heat it upon the coals; then again throw it in the vessel which contains the above-mentioned preparation; do this several times until it becomes fit for use [ie as gold] (23).

From this description, we may discern a repeated sequence of heat-treatment and pickling operations, 
using misy, salt and vinegar. Misy has been firmly identified with basic hydrated ferric sulphates, in particular the mineral copiapite, which, when mixed with salt in solution, form ferric chloride and sulfuric acid $(24,25)$.

The manufacturing process in question would have corresponded to depletion gilding (or silvering), whereby the base metal, copper, is leached out of the surface of the alloy item by oxidation and acid pickling, to leave a gold- or silver-rich layer with a matt texture. A final burnishing operation is required to achieve a bright finish. This is precisely the procedure that was used by the pre-Columbian peoples of the Andes for manufacturing items of tumbaga (ie coppergold-silver alloys) $(26-28)$. The probable recipe that was employed by the ancient American Indians for depletion gilding tumbaga has been reconstructed and it is virtually identical to that given in the Leiden Papyrus X. The steps are as follows (29):

1) Cast an ingot of a copper alloy containing more than about $15 \mathrm{wt} \%$ gold and approximately $5 \mathrm{wt} \%$ silver.

2) Cold-work the ingot with intermediate annealing/quenching stages until the required geometry is achieved. Although relatively hard, such alloys have some workability when in an annealed condition. A black scale of cupric oxide forms on the surface.

3) Coat the item with a pickling preparation in the form of an aqueous paste of pulverised iron sulfate mineral, mixed together with salt and optionally vinegar. As the pickling agent strips off the oxide scale and progressively leaches out silver from the surface, the colour of the surface changes from black, to whitish and eventually to a light brown, characteristic of a matt coating of gold.

4) Finally, burnish the item to produce a shiny yellow surface.

These steps are shown schematically in Figure 2.

The depletion gilding and silvering process work satisfactorily for copper-silver and copper-silver-gold alloys, but not for copper-gold alloys without silver. The process relies on the fact that silver is not highly soluble in copper and when alloyed, eutectic phase separation occurs. Any gold added will enter both the copper- and silver-rich phases. The combination of a heat treatment and acid pickling will preferentially remove the oxidised beta phase from the surface of the material, leaving it silver- or gold-rich, depending on the gold concentration (30).

Figure 3 shows the colour of a $\mathrm{Cu}-10 \mathrm{wt} \% \mathrm{Ag}$ $25 w t \% A u$ alloy coupon before (A) and after (B)

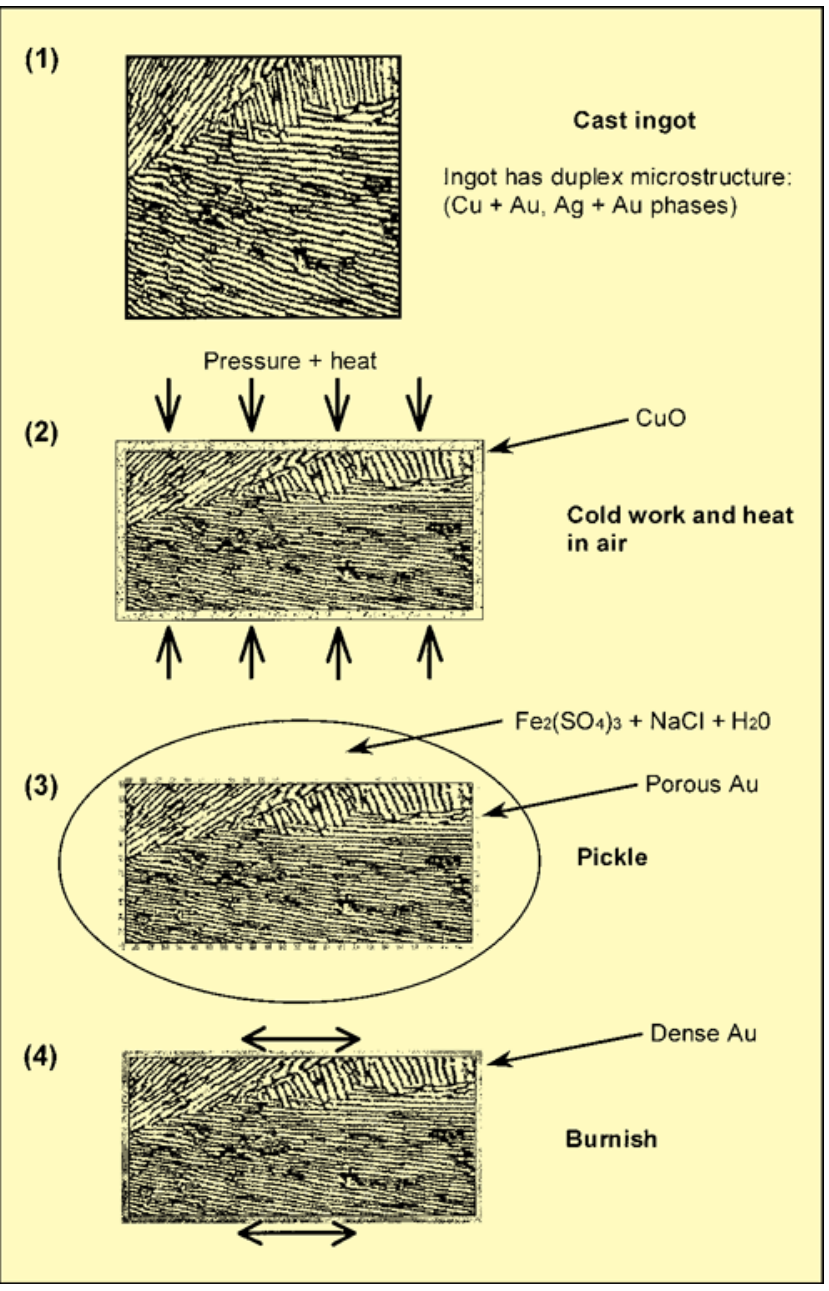

Figure 2 Schematic representation of the procedure for depletion gilding copper alloys containing gold and silver. (1) A copper-silver-gold alloy is prepared and cast as an ingot. (2) The ingot is cold worked to shape and annealed in several successive stages by beating to $500-700^{\circ} \mathrm{C}$ and quenching. A black scale of cupric oxide forms on the surface. (3) The item is coated with a pickling preparation in the form of an aqueous paste of pulverised copiapite or metavoltine, containing ferric sulphate, mixed together with salt and optionally vinegar. The pickling agent strips off the oxide scale and progressively leaches silver from the surface. The resulting gold-rich surface is porous and appears matt. (4) The item is burnished to produce a dense, shiny, gold surface.

depletion gilding and also of a Cu-10wt\%Ag alloy before (C) and after (D) depletion silvering.

This depletion technique has been used successfully by ancient metal-workers in the central Andes to gild articles of sheet metal containing as little as $12 \mathrm{wt} \%$ gold (31). The significant precious metal content of Corinthian Bronze would explain why it 


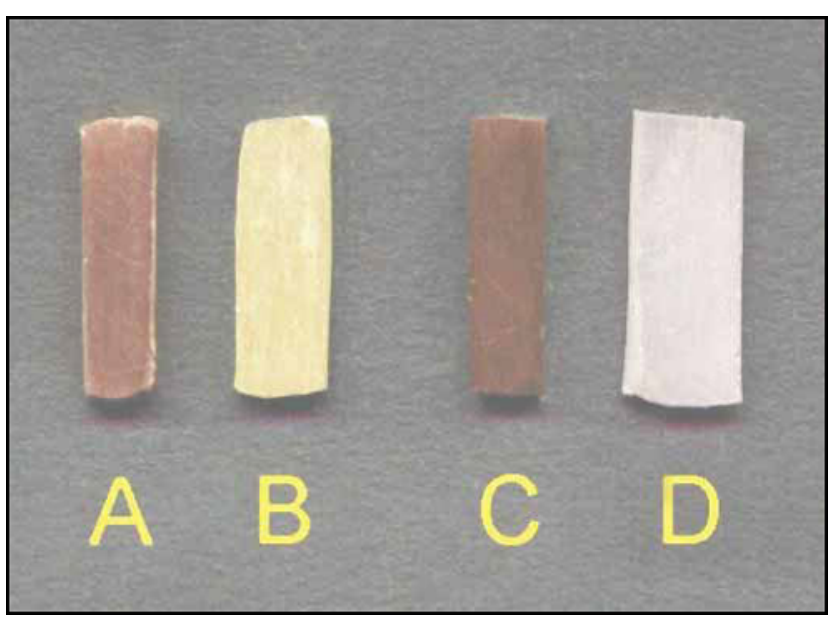

Figure 3 Ingots of a $\mathrm{Cu}-10 w+\% \mathrm{Ag}-25 w+\% \mathrm{Au}$ alloy before $(A)$ and after (B) depletion gilding and also of a Cu$10 w \% \mathrm{Ag}$ alloy before (C) and after (D) depletion silvering.

was so highly valued in the Roman Empire, notwithstanding the fact that it was less than the cost of pure gold while possessing the same surface appearance. It also accounts for the fact that the use of Corinthian Bronze was mostly limited to small domestic items, such as plates, bowls, vases and figurines (32). Such objects are normally fashioned by casting rather than being hammered into shape. This is consistent with the hardness of copper-silver-gold alloys. The doors of the Gate of Nicanor in Herod's Temple were, doubtless, made as large castings, as were the surviving Roman bronze doors of the Pantheon in Rome (33). This supposition finds support in their great weight: Josephus, the 1st century AD historian, mentions that they "could scarcely be moved (on their hinges) by twenty men." (34).

The material evidence for Corinthian Bronze is limited. It has been proved that depletion silvering was used to produce a silvered surface on debased late 3 rd - early 4th century AD denarii and antoniani, containing typically $40 \mathrm{wt} \%$ silver. Metallographic studies of coin samples have shown that the process used was exactly the same as the one that we have reconstructed, involving heating, quenching, pickling and finally burnishing (35). A non-destructive examination of a selection of Celtic gold coins in the Basel Historical Museum has shown that most were made of ternary copper-silver-gold alloys, with gold contents as low as $20 \mathrm{wt} \%$, or even less. There was clear evidence of gold enrichment at the surface consistent with depletion gilding (36). A similar familiarity with copper-silver-gold alloys and their potential has been shown in gold artefacts from Iron Age Britain (37). The apparent lack of depletion-gilded bronze artefacts from Roman contexts may simply mean that they have not been recognized. After abrasion or corrosion of the bronze, the original surface treatment may not be recognized and, moreover, depletion-gilding can easily be mistaken for conventional mercury gilding. The key to the rediscovery of artefacts of Corinthian Bronze must be the identification of copper-silver-gold compositions among antique metal objects. However, the fact that we possess a description of the process of depletion gilding from Roman Egypt, namely the Leiden Papyrus X, as well as identified depletion gilded and silvered artefacts of a similar antiquity, provides sure proof that this technology was in use in the Roman Empire. Indeed, it has been claimed that the colour tones of Corinthian Bronze, as described by Pliny, can be discerned among the bronze vessels depicted in Roman wall paintings from Campania (38).

Other types of gilding were also in use in the Classical World: these processes and the relevant Classical textual sources have been expertly reviewed in a fairly recent German publication (39). Gilding by the application of gold-mercury amalgam was practised in the Mediterranean World since the 2nd or 1st century $\mathrm{BC}$ and it became widely used for gilding bronzes because it was relatively economical and better suited to gilding large surfaces. However, mercury gilding is degraded by the presence of tin and lead in the bronze, elements which enhance the casting properties of the metal. Moreover, mercury gilding, along with the other methods that were used with bronze in antiquity, produces a discrete gold coating with an abrupt interface to the underlying bronze which is susceptible to peeling off the surface while, by contrast, depletion gilding results in a graded interface. Although Corinthian Bronze was considerably more expensive than mercury-gilded bronze, on account of the fact that gold has to be added to the bulk of the bronze instead of being limited to the surface coating, it produces a more durable gilding which is tolerant to the presence of tin and lead, thereby making it particularly advantageous for bronze castings.

Depletion gilding appears to stretch back to the 4th millennium $\mathrm{BC}$, and an example illustrating the application of this technique to debased gold, in the form of a ceremonial dagger, has been identified among the artefacts recovered from the Royal Tombs at $\mathrm{Ur}_{\mathrm{r}}$ in Mesopotamia, dating from the 3rd millennium $\mathrm{BC}$ (40). In the Classical period, the centre of manufacture of Corinthian Bronze, which we have 
identified with depletion-gilded and silvered copper alloys, seems to have been Egypt, including Alexandria. There is substantial evidence that the techniques for colouring metals were especially developed in Egypt and reach back to Pharaonic times (41). It is also significant in this respect that the Leiden Papyrus X was an Egyptian metallurgical text. Therefore, the Alexandrian origin of the doors for the main entrance to the Inner Temple in Jerusalem fits well into this context.

As we have seen, references to Corinthian Bronze run down to the tenth century $\mathrm{AD}$. Yet, its heyday seems to have lasted only about a century and a half, from the generation of Cicero to the last decades of the 1 st century $\mathrm{AD}$. By the early decades of the 2nd century, Corinthian Bronze seems to have been a fashion of the past, for the younger Pliny (the nephew of the encyclopaedist of the same name) describes a newly acquired Corinthian Bronze statuette as an antique (42). By then, the manufacture of Corinthian Bronze had evidently become commercially unattractive, and the Imperial attempts to control its price could only have helped to put a brake on this activity.

It is fair to point out that other interpretations have been given for Corinthian Bronze. According to Jerome Murphy-O'Connor, Corinthian Bronze was simply bronze manufactured in the city of Corinth (43). $\mathrm{He}$ argued that Pliny's references to gold and silver were intended to emphasise the prestige of the bronze, rather than their presence in the metal. Another author who doubts the presence of precious metals in Corinthian Bronze is Donald Engels, who has suggested that it was a class of bronze with a hightin content (about $14 \mathrm{wt} \% \mathrm{Sn}$ ), that he claims was unique to Corinth (44). The boosted tin content lightened the colour and made it harder than normal bronze. However, these proposals are at odds with the ancient sources, which concur that the term Corinthian Bronze referred to specific alloys of copper with gold and silver. Engels was aware of this inconsistency and suggested that a bronze-worker spread the story that the lighter colour was due to the additions of gold and silver. In other words, this interpretation is predicated on the assumption that the alloy called Corinthian Bronze was a forgery, as Engels concedes. However, the high tin content, on its own, would not explain the brilliant appearance of Corinthian Bronze, noted in the ancient sources. Moreover, the Alexandrian provenance of the doors of Nicanor shows that not all Corinthian Bronze was manufactured in Corinth.
A somewhat different interpretation has been offered by Paul Craddock and his co-workers $(45,46)$. In their view, a copper alloy with a low content of gold and silver (typically $<2 \mathrm{wr} \%$ of each of these) and finished with a black patination is genuine Corinthian Bronze. The chief merit of their suggestion is that examples have been found among surviving Roman decorative metalwork and it fits well with the "black Corinthian metal" described in the Syriac "Zosimus" manuscript and mentioned earlier. The text gives the composition of this metal as " 8 parts of gold and 8 parts of silver to 100 parts of copper": in other words, the content of each of the precious metals is less than $7 \%$. The snag with this theory is that it ignores the evidence in the ancient texts, including the very same Syriac manuscript, that Corinthian Bronze had a golden (or silvery) colour (47). The matt black colouring of the alloys described by Craddock et al is almost the exact antithesis of the lustrous appearance of Corinthian Bronze attested in the literature. As pointed out by Engels, this blackish bronze corresponds better with the hepatizon alloy mentioned by Pliny (48). The lower precious metal content in the alloy would account for its inferior standing to true Corinthian Bronze.

\section{THE ORIGINS OF THE ALCHEMISTS' TRANSMUTATION DOCTRINE}

By the early 4th century AD, when the texts of the Graeco-Egyptian author Zosimus of Panopolis were apparently composed, the subject of alchemy had taken recognisable shape and had acquired many of the concepts and nomenclature that are found in later works in this genre $(49,50)$. By then, the Greek terms chemeia / chymeia, which became al-kimiya in Arabic and thence alchemy in English, had come to signify both alloying and "transformation" of metals (51). It may be no coincidence that the word chemeia is phonetically close to chemia, the native name for Egypt, transliterated into Greek.

Towards the end of the 19th century, the accomplished French chemist and politician, Pierre Eugène Marcellin Berthelot, and his co-workers collected and studied the ancient Greek alchemical texts. From their readings they deduced that the concept of transmutation of metals, the primary goal of alchemy, derived from the practice of surface colouring, or tincturing metals $(52-54)$. An important early document that deals broadly with this subject is the Leiden Papyrus X, already mentioned in 
connection with Corinthian Bronze. Of the 99 chemical recipes contained in this papyrus, processes for colouring metal surfaces, mostly to resemble gold or silver, feature prominently.

In this regard, the emphasis given in the early alchemical texts to tincturing is striking (55). In Latin the term used is tinctura, which is baphê in the Greek original, meaning dipping or dyeing. The more appropriate word for colouring, chrôsis is used in the Leiden Papyrus X. Interestingly, the type of reflux apparatus commonly used by alchemists for treating metals with vapours, was called a kêrotakis, a Greek word meaning artist's palette $(56,57)$.

The development of Corinthian Bronze is therefore seen to be part and parcel of the formative phase of the evolution of alchemy, which occurred in Egypt. For the reasons given above, it is hardly surprising to find descriptions and allusions to depletion gilding in the early alchemical literature, although only in one surviving treatise, the Syriac "Zosimus" manuscript, is the name Corinthian Bronze remembered. Clearly identifiable references to depletion gilding occur in the Physica et Mystica attributed to Democritus (58) and also in the Mappae Clavicula, written in the 9th - 10th centuries A.D, which is more a rational treatise on alloys and pigments than a book of speculative alchemy (59).

Initially only true gold was defined as such, but the definition in the alchemical texts was later extended to debased gold. Eventually any metal which had the colour of gold, including metals with a gilded surface was categorised as gold $(60,61)$. Hence the process of depletion gilding became regarded as one of transmutation of base metal to gold. The two notions became thoroughly mixed and we can see that the aphorism of the shadowy Alexandrian alchemist Agathodaimon, describing the colour changes accompanying the transmutation process, applies equally to the steps in depletion gilding:

"After the refinement of copper and its blackening and later whitening there will be the solid yellowing" (62).

To draw further parallels, we may see the Alchemists' Philosopher's Stone or Elixir (from the Greek xêrion = dry powder, via the Arabic al-iksir), the wonder agent of the transmutation process, as corresponding to the commonplace mineral referred to in the early texts as misy, which effected depletion gilding (63). Significantly, both are minerals (or stones). Moreover, copiapite, the iron sulphate mineral which has widely been identified with misy, is itself



Figure 4 An image of an archetypal alchemist at work in his laboratory, among his tools and utensils. 16 th century engraving by $H$. Weiditz.

yellow in colour and this fact may have added to its mystique (64).

However chaotic and esoteric were the ideas that grew out of the concept of transmutation, at least some of the practising alchemists kept their feet on the ground and preserved the practical legacy of their ancient mentors (see Figure 4). We see this, for example, in an oval medallion struck by the 17 th century Augustinian monk and alchemist, Wenzel Seyler (65). An inscription on the piece records that Seyler transmuted it to gold in an experiment performed in 1677. This medallion has survived and scientific analysis has shown this to be an 11 carat gold-silver-copper alloy that had undergone depletion gilding (66).

\section{ABOUT THE AUTHOR}

David Jacobson holds doctorates in Materials Science from the University of Sussex and in Classical Archaeology from the University of London. Following a spell of teaching and research in Materials Engineering at the Ben Gurion University of the Negev in Israel, he established a career in industrial research, developing specialist technical expertise in metal joining. While serving as Head of the Materials Fabrication Division at the GEC-Marconi Hirst Research Centre, he co-authored a textbook on 'The Principles of Soldering and Brazing'. Currently he works as a consultant on electronic materials and holds a part-time appointment at the Centre of Rapid Design and Manufacture attached to the Buckinghamshire University College. He also teaches an undergraduate course on the Jews and the Classical World at University College, London and his research interests include archaeo-metallurgy relating to the ancient Near East. 


\section{REFERENCES}

1 Pliny, Naturalis Historia. 34.1

2 Pliny, Noteralis Historia, 34.8

3 Pliny, Naturalis Historia, 37.49

4 D.M. Jacobson and M.P. Weitzman, Amer. J.Archreol, 1992, 96, 238-39

5 Plutarch Mordia, De Pythide ordatits, 2 (395B-D); Petronius, Satyricon 50; Pliny, Naturalis Hestoria, 34.6; Florus 1.32; Orosius 5.3

6 Cicero Tusculatide Disputationes, 4.32; Plutarch Mordia, De Pythide oracilis, 2 (395B)

7 Josephus, Bellum Frdaicum, 5.201. On other ancient references to the Nicanor Gate, see Jacobson and Weitzman (reference 4), pp. 24041

8 Mishnah, Middoth 2:3

9 Tosephta, Yoma, 2:4; Yoma 3:8, on Mishnah Yoma 3:10; see Jacobson and Weitzman 1992 (reference 4), p. 240 and note 29

10 J.P. Kane, Joumal of Jewish Studies, 1978, 23, 268-32

11 Tosephta, Yoma, 2:4; Jerusalem Talmud, Yoma, 3:8; Babylonian Talmud, Yoma, 38a

12 Jacobson and Weitzman (reference 4), p. 240

13 M.P. Weitzman, 'The Syriac version of the Old Testament,' Cambridge University Press, Cambridge, 1999, p. 261

14 D.M. Jacobson and M.P. Weitzman, The Clasical Quatrerly, 1995, 45 (2), 581

15 Cambridge MS. Mm 6.29, folio 41v. See W. Wright, A Catalogue of the Syriac Manuscripts Preserved in the Library of the University of Cambridge, Cambridge University Press, Cambridge, 1901, pp. 1036-1037

16 Jacobson and Weitzman (reference 14), p. 582

17 R Duval (ed.), 'Lexicon Syriacum auctore Hassano bar Bahlule', 'Typographaeus Republicae, Paris, 1888-1901, p. 1238

18 Jacobson and Weitzman (reference 4), pp. 241-44

19 Pausanias ii 3, 3 (heating and quenching). In the Syriac "Peshitta" translation of 1 Kings, the Hebrew phrase "burnished bronze." is renderod as "Corinthian Bronze".

20 E.R, Caley, Joumal of Chemical Education, 1926, 3,1149.68

21 R. Halleux, R, 'Les alchimistes grecs. I: Papyrus de Leyde, Papyrus de Stockholm, fragments de recettes,' Fditions Budé, Paris, 1981, pp. 84-109

22 L.B. Hunt, Gold Bull, 1976, 9, 21-31

23 Calcy (reference 20), p. 1153

24 Jacobson and Weitzman (reference 4), p. 242

25 J.W. Mellor, A Comprehensive Treatise on Inorganic and Theoretical Chemistry' Longmans, Green and Co., London and New York, 1935, Vol. 14, 329-30

26 T. del Solar and M. Grimwade; Awrm, 1982, 12,37-45

27 Jacobson and Weitzman (reference 4), p. 244

28 D.M. Jacobson and J.S. McKenzic, Interdisciphlinaty Science Revieus, 1992, 17,327

$29 \mathrm{H}$. Lechtman, in 'The Beginning of the Use of Metals and Alloys: Papers from the Second International Conference on the Beginnings of the Use of Metals and Alloys, Zhengzhou, China, 21-26 October 1986, ed. R Maddin, M.I.T. Fress, Cambridge, MA, 1988 , p. 374

$30 \mathrm{~L}$. Cope, in 'Methods of Chemical and Metallurgical Investigations of Ancient Coinage: A Symposium Held by the Royal Numismatic Society at Burlington House, London, on 9-11 December 1970 (RNS special Publication Na 8), ed. E.T. Hall and D.M. Metcalf, Royal Numismatic Society, London, 1972, pp. 267-268

31 Lechtman (reference 29), p. 373

32 Pliny, Natusalis Historia, 34.7; Petronius, Satyricon, 50; Suetonius, Arugustas, 70.2

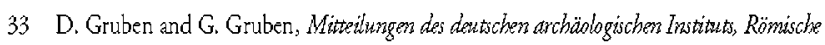
Abteilung, 1997, 104, 3-52

34 Josephus, Beltrm frudaioum6. 293

35 L.H. Cope, in 'Methods of Chemical and Metallurgical Investigation of Ancient Coinage, ed. ET. Hall and D.M. Metcalfe, Royal Numismatic Society, London, 1972 , pp. 266-71

36 W.B. Stern, in 'Prehistoric Gold in Europe,' ad. G. Morteani and J.P. Northover, Kluwer Academic Publishers, Amsterdam, 1995, pp. 317-28

37 R.F Tylecote, A History of Metallurgy;' The Metals Society, London, 1976, p. 48

38 A.E. Riz, 'Bronzegefässe in der römisch-pompejanischen Wandmalerei,' Philipp yon Zabern, Mainz, 1990, p. 21

39 R Fuchs et ah, 'Gold und Vergoldung bei Plinius dem Alteren,' Attempto Verlag, Tübingen, 1993 , pp. 56-70

40 S. La Niece, Irag, 1995, 57, 41-47

41 Halleux (reference 21), p. 41

42 Pliny, Episis lae 3.6

43 J. Murphy-O'Connor, Rewre Bibligue, 1983, 90,80-93

44 D.W. Engels, 'Roman Corinth. An altemative model for the Classical city' University of Chicago, Chicago / London, 1990, pp. 36-37

45 A.R Giumlia-Mair and P.T. Craddock, Antike Welt, 1993, 24 (5), 1-62; Craddock and Giumlia-Mair, in S. La Niece and P. Craddock (eds.), Metal plating and patination: cultural, technical and historical developments,' Butterworth Heinemann, Oxford, 1993, pp. 102-127; Craddock, Gold Bull, 1982, 15, 69-72

46 P.T. Craddock, Gold Bull, 1982, 15, 69-72.

47 Jacobson and Weitman (reference 14), pp. $580-83$

48 Engels (reference 44), pp. 206-207, note 66

49 P.E.M. Berthelot and C.E. Ruelle, 'Collection des anciens alchimistes grecs, 'F Steinheil, Paris, 1888, Vol. 2, pp. 107-252

50 F. Sezgin, 'Geschichte der arabischen Schriftums,' EJ. Brill, Leiden, 1971, Vol. 4, pp. $73-77$

51 J.M. Stillman, "The Story of Early Chemistry' Appleton \& Co, New York / London, 1924,pp $135-83$

52 Berthelot and Ruelle (reference 49), Vol. 1, pp $19-20$

53 P.E.M. Berthelot, 'Introduction a l'etude de la chimie des anciens et du moyen age, G. Steinheil, Paris, 1889, pp. 53-62

54 G.B. Kauffman, Gold Bull, 1985, 18, 38-40

55 Jacobson and McKenzie (reference 28), p. 327

56 Berthelot and Ruelle (reference 49), Vol. 1, pp. 14251

57 J. Lindsay, 'The Origins of Alchemy in Graeco-Roman Egypt,' Muller, London, 1970, 246

58 Berthelot and Ruelle (reference 49), Vol. 2, p. 46

59 C.S. Smith and J.G. Hawthome, Trars. Amer. Phil. Soc, New Series, 1974, 64 (4), pp. $32,39,59$

60 Berthelot and Ruelle (reference 49), Vol. 1, p. 20

61 Kauffman (reference 54), 39-40

62 Berthelot and Ruelle (reference 49), Vol. 2, p. 115

63 Kauffman (reference 54), pp. 69-74

64 D.A. Scott, Joumal of the Historical Merallurgical Society, 1983, 17, 110; Jacobson and Mckenzie (reference 28), 242

65 Kauffman (reference 54), 113-114 and Figure 32

66 V. Karpenko, Ambix, 1988, 35, 73-74 